Article

\title{
Structures and Activity of New Anabaenopeptins Produced by Baltic Sea Cyanobacteria
}

\author{
Lisa Spoof ${ }^{1, *}$, Agata Błaszczyk $^{2}$, Jussi Meriluoto ${ }^{1}$, Marta Cegłowska ${ }^{2}$ and \\ Hanna Mazur-Marzec ${ }^{2}$ \\ Received: 22 October 2015; Accepted: 23 December 2015; Published: 30 December 2015 \\ Academic Editor: Orazio Taglialatela-Scafati \\ 1 Biochemistry, Faculty of Science and Engineering, Åbo Akademi University, Tykistökatu 6 A, 20520 Turku, \\ Finland; jussi.meriluoto@abo.fi \\ 2 Department of Marine Biotechnology, University of Gdańsk, Al. Marszałka Piłsudskiego 46, 81-378 Gdynia, \\ Poland; agata.blaszczyk@ug.edu.pl (A.B.); ma.ceglowska@gmail.com (M.C.); biohm@ug.edu.pl (H.M.-M.) \\ * Correspondence: lspoof@abo.fi; Tel.: +358-2-21531; Fax: +358-2-2157553
}

\begin{abstract}
Anabaenopeptins, bioactive cyclic hexapeptides, were isolated by preparative reversed-phase high performance liquid chromatography from an extract of Baltic Sea cyanobacterial bloom material composed of Nodularia spumigena (50\%), Aphanizomenon flos-aquae (40\%) and Dolichospermum spp. (10\%). Five new anabaenopeptins and nine previously known anabaenopeptins were isolated, and their putative structures were determined by tandem mass spectrometry. The activity of the peptides against carboxypeptidase A and protein phosphatase 1 as well as chymotrypsin, trypsin and thrombin was tested. All anabaenopeptins inhibited carboxypeptidase A (apart from one anabaenopeptin variant) and protein phosphatase 1 with varying potency, but no inhibition against chymotrypsin, trypsin and thrombin was observed.
\end{abstract}

Keywords: Anabaenopeptins; nodulapeptins; Baltic Sea; cyanobacteria; Nodularia spumigena; Aphanizomenon flos-aquae; Dolichospermum spp.; carboxypeptidase A; protein phosphatase 1

\section{Introduction}

Marine and freshwater cyanobacteria are one of the most interesting sources of novel biologically active compounds including cytotoxic metabolites, protease inhibitors and antimicrobial agents [1-3]. Many secondary metabolites of cyanobacteria are cyclic or linear peptides. Most cyanobacterial peptidic compounds belong to distinct oligopeptide families or classes, such as micropeptins, anabaenopeptins, aeruginosins, spumigins, cyclamides, microginins, microviridins, and the more extensively studied hepatotoxins microcystins and nodularins $[4,5]$.

Anabaenopeptins were named after the cyanobacterium Anabaena flos-aquae from which the first anabaenopeptins were isolated as minor compounds accompanying microcystins and the rare neurotoxic alkaloid anatoxin-a(S) [6]. To date, at least 96 anabaenopeptins have been reported in the literature (Supplementary Material Table S1). Whilst these peptides are structurally related, with amino acid substitutions being responsible for the observed diversity, their nomenclature is not fully systematic [4]. Their names often refer to the taxon from which they have been identified or a geographic locality of discovery, complemented with suffices describing the variety. Some anabaenopeptins, especially those identified lately, have the molecular weight as one part of the name, which may be confusing since several anabaenopeptins can have the same molecular weight. Some compounds structurally recognized as anabaenopeptin variants were named in the original papers as oscillamides, isolated from Planktothrix (Oscillatoria) [7], nodulapeptins (NPs) from Nodularia [8] and ferintoic acids from Microcystis [9]. These compounds were discovered concomitantly with anabaenopeptins A to F $[10,11]$. Anabaenopeptins such as lyngbyaureidamides 
A and B were isolated from freshwater Lyngbya sp. [12] while marine Lyngbya sp. has been the source for pompanopeptin B [13], a compound similar to anabaenopeptin J and I originally found in Aphanizomenon [14]. The first marine anabaenopeptin-related compounds, keramamides [15], konbamide [16], and mozamides [17] were from the sponge Theonella originating from Japan and Mozambique. Brunsvicamides A-C isolated from the cyanobacteria Tychonema sp. (order Oscillatoriales) are closely related in structure to the marine sponge-derived anabaenopeptins [18] indicating a cyanobacterial origin [19]. Schizopeptin, isolated from a soil sample containing Schizothrix sp., is an example of a compound produced by terrestrial cyanobacteria [20]. Recently, several anabaenopeptin variants were detected in the Nostocaelan genera Nostoc, Desmonostoc and Brasilonema isolated from plant leaves [21].

All of the above-mentioned anabaenopeptins (APs) are cyclic peptides comprised of a ring of five amino acid residues connected to an exocyclic residue through an ureido linkage. The general structure of anabaenopeptins is $\mathrm{X}_{1}$-CO-[Lys- $\left.\mathrm{X}_{3}-\mathrm{X}_{4}-\mathrm{MeX}_{5}-\mathrm{X}_{6}\right]$ [4], where the brackets indicate the cyclic part of the peptide, and $X_{1}$ and $X_{3}$ to $X_{6}$ are variable amino acid residues. The structure contains both protein and non-protein amino acids. The peptide ring is derived from the cyclisation of the C-terminal carboxyl to the primary $\varepsilon$-amine of the $N$-terminal lysine. In the cyanobacterial anabaenopeptins, the ureido-bond and the D-Lys moiety are conserved in the structure, while the other residues vary and are in L-configuration. In the sponge-derived anabaenopeptins, both D- and L-configuration of the Lys residue occurs. A common feature of many APs is the presence of a homo-amino acid residue in position 4 and an $\mathrm{N}$-methylated amino acid residue in position 5 . An exception to this is demonstrated in the sponge-derived paltolides $\mathrm{A}-\mathrm{C}$ where the residue in position 4 is L-Leu [22]. There are at least 87 published structures of anabaenopeptins isolated from cyanobacteria and nine sponge-derived anabaenopeptins. In the present paper, the anabaenopeptins with a letter code (such as anabaenopeptin A) are spellt out whereas those anabaenopeptins which are called by their molecular weight (such as AP 813) are abbreviated.

Anabaenopeptins are assembled by a non-ribosomal peptide synthetase (NRPS) enzyme complex, which has a modular structure. Each module contains specific functional domains responsible for adenylation and thiolation of the activated amino acid monomers, and elongation of the peptide sequence. The relaxed substrate specificity of NRPSs is considered to be the reason for the structural richness of peptides found in cyanobacteria [23]. The associated gene clusters can encode either a single starter module as in Nostoc and Nodularia or two starter modules as in Anabaena [24]. Several low molecular weight (MW) peptides synthetised via NRPS pathway are capable of inhibiting proteolytic enzymes, but the strength and specificity of the enzyme inhibition varies between the classes of peptides and the individual peptide variants. Characteristic for many anabaenopeptins is the inhibition of zinc-containing metalloexopeptidases such as carboxypeptidase A (CPA) and B (CPB) $[14,25]$. In experiments driven by pharmacological interests, anabaenopeptins have been shown to inhibit also carboxypeptidase U [26] and carboxypeptidase TAFIa, the thrombin activatable fibrinolysis inhibitor, important in the coagulation-fibrinolysis system [27]. Only a few studies so far have demonstrated activity of anabaenopeptins towards serine endopeptidases such as elastase, trypsin and chymotrypsin [28-30]. Anabaenopeptins have also been shown to inhibit serine/threonine protein phosphatases [31,32]. The biological role of anabaenopeptins is still uncertain, but theories include acting as a defense mechanism against parasites like chytrid fungi [33] and pathogenic amoeba [34], or to control cyanobacterial cell density [35].

In the present work, 14 anabaenopeptins were isolated from a bloom of Baltic Sea cyanobacteria consisting of Nodularia, Aphanizomenon and Dolichospermum spp. by preparative high performance liquid chromatography (HPLC). The putative structures of the peptides were determined by liquid chromatography coupled to tandem mass spectrometry (LC-MS/MS), and their activities towards carboxypeptidase A, protein phosphatase 1 and three proteolytic enzymes were tested. 


\section{Results and Discussion}

In the brackish Baltic Sea, summer blooms of the filamentous and nitrogen-fixing cyanobacteria are frequently encountered. The blooms are mainly composed of toxic, nodularin-producing Nodularia spumigena and Aphanizomenon flos-aquae, which has been considered non-toxic. In coastal waters, but occasionally also in the open sea area, Dolichospermum (Anabaena) spp.-probable producers of microcystins - can be observed [36]. Our present study showed that bloom-forming Baltic Sea cyanobacteria, consisting mainly of N. spumigena, are an abundant source of bioactive cyanobacterial peptides.

The rough order of increasing hydrophobicity of the different peptide classes detected in the preliminary solid-phase extraction (SPE) fractionations of our sample was spumigins [4,5] (least hydrophobic, eluted with $20 \%-60 \%$ acidic methanol), aeruginosins [4,5] (eluted with $40 \%-60 \%$ acidic methanol), nodularins/microcystin-LR (eluted with $60 \%-80 \%$ acidic methanol) and anabaenopeptins (eluted with $60 \%-80 \%$ acidic methanol). Some of the anabaenopeptin variants have hydrophobicity equal to that of nodularin- $R /$ microcystin-LR resulting in co-elution. The general oligopeptide pattern in the currently studied Baltic Sea cyanobacterial sample resembled that of Nodularia [8,37], which was expected since $50 \%$ of the material was Nodularia. Microcystin-LR originated most likely from Dolichospermum [36]. Baltic Sea Aphanizomenon has not been shown to produce anabaenopeptins (unpublished results by Mazur-Marzec, and [38]) although anabaenopeptins I and J were originally isolated from Japanese Aphanizomenon flos-aquae [14]. Anabaenopeptins were present both in the $60 \%$ and $80 \%$ SPE fractions. The previously discovered anabaenopeptin E $(m / z$ 851), AP $841(m / z$ 842) [37], and a new anabaenopeptin with $m / z$ 824, with the planar structure Ile + CO[Lys + Val + Hph + MeHty + Ser] were detected in the $60 \%$ SPE fraction but only in low amounts. During the first preparative HPLC purification (System 1) of the 80\% SPE fraction containing most of the APs, 15 time segments were collected, each of which was further purified in the second preparative HPLC system. The second preparative HPLC (System 2) resulted in 18 fractions containing one or several APs each. Seventeen anabaenopeptins were detected eight of which were regarded as new ones. Five of them were isolated in a purified form without coelution of other anabaenopeptins or nodularin. The isolated peptides with their observed $m / z$ values, putative planar structures and approximative amounts are listed in Table 1 . The concentrations of the anabaenopeptins were calculated by comparing the peak areas at $214 \mathrm{~nm}$ with the mean peak areas of the standards anabaenopeptin A and B (both $10 \mu \mathrm{g} / \mathrm{mL}$ ).

Anabaenopeptins were identified and their putative structures deduced from the LC-MS/MS fragmentation spectra by comparison to already known peptides and their fragment ions [39-41]. LC-MS/MS cannot distinguish between isomeric amino acids or provide information on stereochemistry. The stereochemistry analyses will need further study, and the isolated compounds may have different isomers. The real compounds responsible for the activity will be confirmed after stereochemistry elucidation by NMR or amino acid analysis. In addition, the presence of Leu cannot be distinguished from that of Ile. When it comes to Leu and Ile, the putative structural assignments of the peptides are based on analogy with earlier known structures. Under the conditions used in this study, fragmentation spectra with a high number of product ions were obtained (Figures 1-5). The identification of the peptide structures was based on the existing information about the known anabaenopeptin components and their location in the molecule. The ion signals occurring in the spectra at low $m / z$ values indicated the presence of specific units, e.g., Lys $(m / z$ 84, 129), MeHty $(m / z 107,164)$ or Phe $(m / z 120)$. The presence and sequence of the units was confirmed by the loss of respective residues from molecular ion and from fragment ions (e.g., $m / z 128$ for Lys, $m / z 191$ for MeHty, $m / z 147$ for Phe). In anabaenopeptins with AcSer or MetO in position 6, a loss of 60 Da or $64 \mathrm{Da}$, respectively, from pseudomolecular ion and some other fragment ions was usually observed. These units correspond to the loss of $\mathrm{CH}_{3} \mathrm{COOH}$ from AcSer and $\mathrm{CH}_{3} \mathrm{SOH}$ from MetO. For example, in the fragmentation spectrum of NP 865 (Figure 4), which contains AcSer, an ion signal at $m / z 806$ is observed, while the spectrum of NP 883, with MetO in position 4, is characterized by the presence of a high intensity ion signal at $m / z 820$ (Figure 1). In the process of structure elucidation, a series of $b$ and 
$y$-ions formed by the cleavage of peptide bonds, as well as $a$-ions formed by the loss of carbonyl group $(\mathrm{CO})$, provided the most valuable information on the sequence of residues in the peptides.

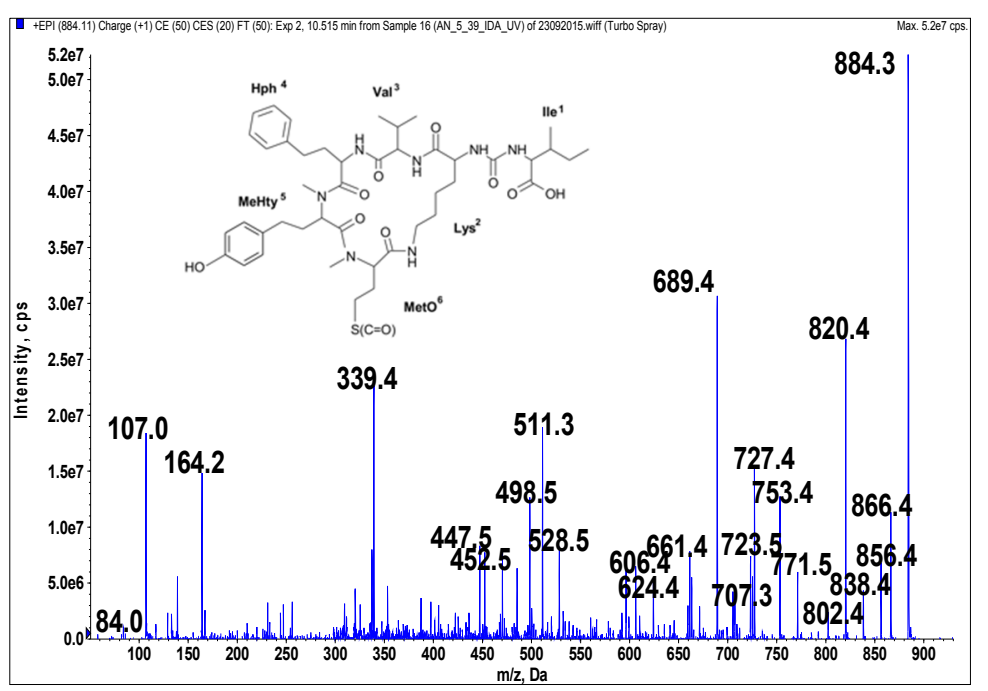

Figure 1. Schematic structure and mass fragmentation spectrum of anabaenopeptin NP 883. The structure of the peptide (Ile $+\mathrm{CO}[\mathrm{Lys}+\mathrm{Val}+\mathrm{Hph}+\mathrm{MeHty}+\mathrm{MetO}])$ was deduced on the basis of the following fragments: $866\left[\mathrm{M}+\mathrm{H}-\mathrm{H}_{2} \mathrm{O}\right], 856[\mathrm{M}+\mathrm{H}-\mathrm{CO}], 838\left[\mathrm{M}+\mathrm{H}-\mathrm{CO}-\mathrm{H}_{2} \mathrm{O}\right]$, $820\left[\mathrm{M}+\mathrm{H}-\mathrm{CH}_{3} \mathrm{SOH}\right.$ (from MetO)], $802\left[\mathrm{M}+\mathrm{H}-\mathrm{CH}_{3} \mathrm{SOH}-\mathrm{H}_{2} \mathrm{O}\right.$ ), $771[\mathrm{M}+\mathrm{H}-\mathrm{Ile}], 753$ $\left[\mathrm{M}+\mathrm{H}-\mathrm{Ile}-\mathrm{H}_{2} \mathrm{O}\right], 727[\mathrm{M}+\mathrm{H}-(\mathrm{Ile}+\mathrm{CO})], 723[\mathrm{M}+\mathrm{H}-\mathrm{Hph}], 707\left[\mathrm{M}+\mathrm{H}-\mathrm{Ile}-\mathrm{CH}_{3} \mathrm{SOH}\right]$, $689\left[\mathrm{M}+\mathrm{H}-\mathrm{Ile}-\mathrm{CH}_{3} \mathrm{SOH}-\mathrm{H}_{2} \mathrm{O}\right], 624[\mathrm{M}+\mathrm{H}-(\mathrm{Hph}+\mathrm{Val})], 606\left[\mathrm{M}+\mathrm{H}-(\mathrm{Hph}+\mathrm{Val})-\mathrm{H}_{2} \mathrm{O}\right]$, $528\left[\mathrm{M}+\mathrm{H}-\mathrm{Ile}-\mathrm{Hph}-\mathrm{CH}_{3} \mathrm{SOH}-\mathrm{H}_{2} \mathrm{O}\right], 511[\mathrm{M}+\mathrm{H}-\mathrm{Ile}-(\mathrm{Hph}+\mathrm{Val})], 452[\mathrm{MeHty}+\mathrm{Hph}$ $+\mathrm{Val}+\mathrm{H}], 339[\mathrm{MetO}+\mathrm{MeHty}+\mathrm{H}], 447\left[\mathrm{M}+\mathrm{H}-\mathrm{Ile}-(\mathrm{Hph}+\mathrm{Val})-\mathrm{CH}_{3} \mathrm{SOH}\right], 164 \mathrm{MeHty}, 107$ $\left[\mathrm{CH}_{2} \mathrm{PhOH}\right], 84$ Lys-immonium ion.

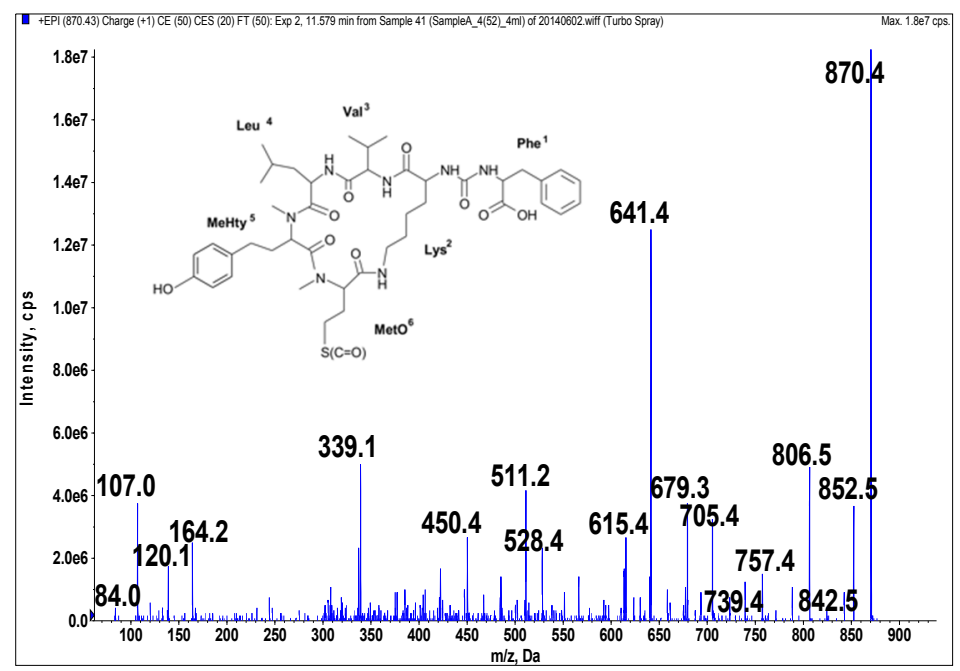

Figure 2. Schematic structure and mass fragmentation spectrum of anabaenopeptin NP 869. The structure of the peptide (Phe $+\mathrm{CO}[\mathrm{Lys}+\mathrm{Val}+\mathrm{Leu}+\mathrm{MeHty}+\mathrm{MetO}]$ ) was deduced on the basis of the following fragments: $852\left[\mathrm{M}+\mathrm{H}-\mathrm{H}_{2} \mathrm{O}\right], 842[\mathrm{M}+\mathrm{H}-\mathrm{CO}], 806\left[\mathrm{M}+\mathrm{H}-\mathrm{CH}_{3} \mathrm{SOH}\right.$ (from MetO)], 788 $\left[\mathrm{M}+\mathrm{H}-\mathrm{CH}_{3} \mathrm{SOH}-\mathrm{H}_{2} \mathrm{O}\right.$ ), $757[\mathrm{M}+\mathrm{H}-\mathrm{Leu}], 739\left[\mathrm{M}+\mathrm{H}-\mathrm{Leu}-\mathrm{H}_{2} \mathrm{O}\right], 705\left[\mathrm{M}+\mathrm{H}-\mathrm{Phe}-\mathrm{H}_{2} \mathrm{O}\right]$, $679[\mathrm{M}-\mathrm{MeHty}+\mathrm{H}], 641\left[\mathrm{M}+\mathrm{H}-\mathrm{Phe}-\mathrm{CH}_{3} \mathrm{SOH}-\mathrm{H}_{2} \mathrm{O}\right], 615\left[\mathrm{M}-\mathrm{MeHty}+\mathrm{H}-\mathrm{CH}_{3} \mathrm{SOH}\right], 528$ $\left[\mathrm{M}+\mathrm{H}-\mathrm{Phe}-\mathrm{Leu}-\mathrm{CH}_{3} \mathrm{SOH}-\mathrm{H}_{2} \mathrm{O}\right], 511[\mathrm{M}+\mathrm{H}-\mathrm{Phe}-(\mathrm{Leu}+\mathrm{Val})], 339[\mathrm{MetO}+\mathrm{MeHty}+\mathrm{H}]$, $164 \mathrm{MeHty}, 120$ Phe-immonium ion, $107\left[\mathrm{CH}_{2} \mathrm{PhOH}\right], 84$ Lys-immonium ion. 


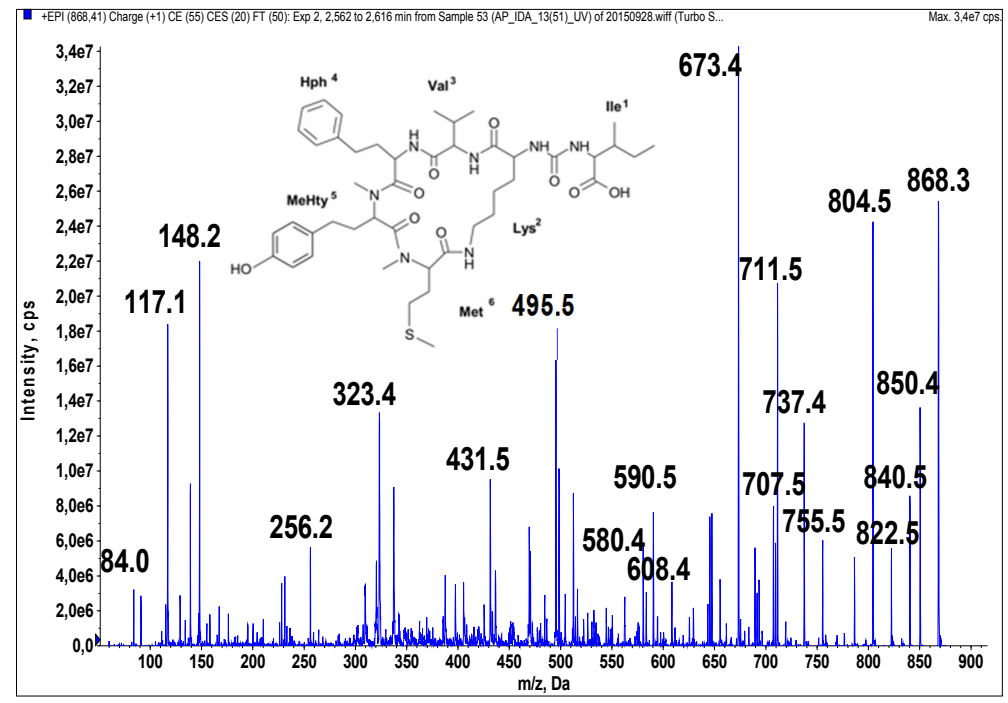

Figure 3. Schematic structure and mass fragmentation spectrum of anabaenopeptin NP 867. The structure of the peptide (Ile $+\mathrm{CO}[\mathrm{Lys}+\mathrm{Val}+\mathrm{Hph}+\mathrm{MeHty}+\mathrm{Met}]$ ) was deduced on the basis of the following fragments: $850\left[\mathrm{M}+\mathrm{H}-\mathrm{H}_{2} \mathrm{O}\right], 840[\mathrm{M}+\mathrm{H}-\mathrm{CO}], 822\left[\mathrm{M}+\mathrm{H}-\mathrm{CO}-\mathrm{H}_{2} \mathrm{O}\right]$, $755[\mathrm{M}+\mathrm{H}-\mathrm{Ile}], 737\left[\mathrm{M}+\mathrm{H}-\mathrm{Ile}-\mathrm{H}_{2} \mathrm{O}\right], 711[\mathrm{M}+\mathrm{H}-(\mathrm{Ile}+\mathrm{CO})], 707[\mathrm{M}+\mathrm{H}-\mathrm{Hph}], 693[\mathrm{M}+\mathrm{H}$ $\left.-(\mathrm{Ile}+\mathrm{CO})-\mathrm{H}_{2} \mathrm{O}\right], 608[\mathrm{M}+\mathrm{H}-(\mathrm{Hph}+\mathrm{Val})], 590\left[\mathrm{M}+\mathrm{H}-(\mathrm{Hph}+\mathrm{Val})-\mathrm{H}_{2} \mathrm{O}\right], 580[\mathrm{M}+\mathrm{H}-$ $(\mathrm{Hph}+\mathrm{Val})-\mathrm{CO}], 495[\mathrm{M}+\mathrm{H}-\mathrm{Ile}-(\mathrm{Hph}+\mathrm{Val})], 323[\mathrm{MeHty}+\mathrm{Met}+\mathrm{H}], 84$ Lys-immonium ion.

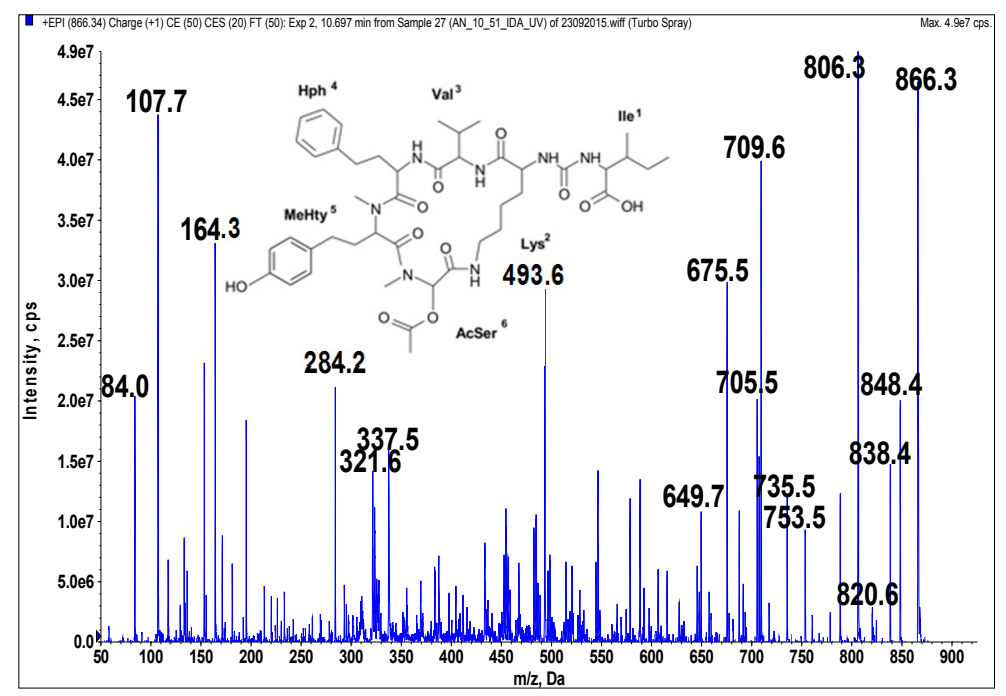

Figure 4. Schematic structure and mass fragmentation spectrum of anabaenopeptin NP 865. The structure of the peptide (Ile $+\mathrm{CO}[\mathrm{Lys}+\mathrm{Val}+\mathrm{Hph}+\mathrm{MeHty}+\mathrm{AcSer}]$ ) was deduced on the basis of the following fragments: $848\left[\mathrm{M}+\mathrm{H}-\mathrm{H}_{2} \mathrm{O}\right], 838[\mathrm{M}+\mathrm{H}-\mathrm{CO}], 820\left[\mathrm{M}+\mathrm{H}-\mathrm{CO}-\mathrm{H}_{2} \mathrm{O}\right]$, $806\left[\mathrm{M}+\mathrm{H}-\mathrm{CH}_{3} \mathrm{COOH}\right.$ (from AcSer)], $753[\mathrm{M}+\mathrm{H}-\mathrm{Ile}], 735\left[\mathrm{M}+\mathrm{H}-\mathrm{Ile}-\mathrm{H}_{2} \mathrm{O}\right], 709[\mathrm{M}+\mathrm{H}-$ $(\mathrm{CO}+\mathrm{Ile})], 705[\mathrm{M}+\mathrm{H}-\mathrm{Hph}], 675\left[\mathrm{M}+\mathrm{H}-\mathrm{Ile}-\mathrm{CH}_{3} \mathrm{COOH}-\mathrm{H}_{2} \mathrm{O}\right], 649[\mathrm{M}+\mathrm{H}-(\mathrm{CO}+\mathrm{Ile})-$ $\left.\mathrm{CH}_{3} \mathrm{COOH}\right], 493[\mathrm{M}+\mathrm{H}-\mathrm{Ile}-(\mathrm{Hph}+\mathrm{Val})], 337\left[\mathrm{M}+\mathrm{H}-\mathrm{Ile}-(\mathrm{Hph}+\mathrm{MeHty})-\mathrm{CH}_{3} \mathrm{COOH}\right], 321$ $[\mathrm{MeHty}+\mathrm{AcSer}+\mathrm{H}], 164 \mathrm{MeHty}, 107\left[\mathrm{CH}_{2} \mathrm{PhOH}\right], 84$ Lys-immonium ion. 


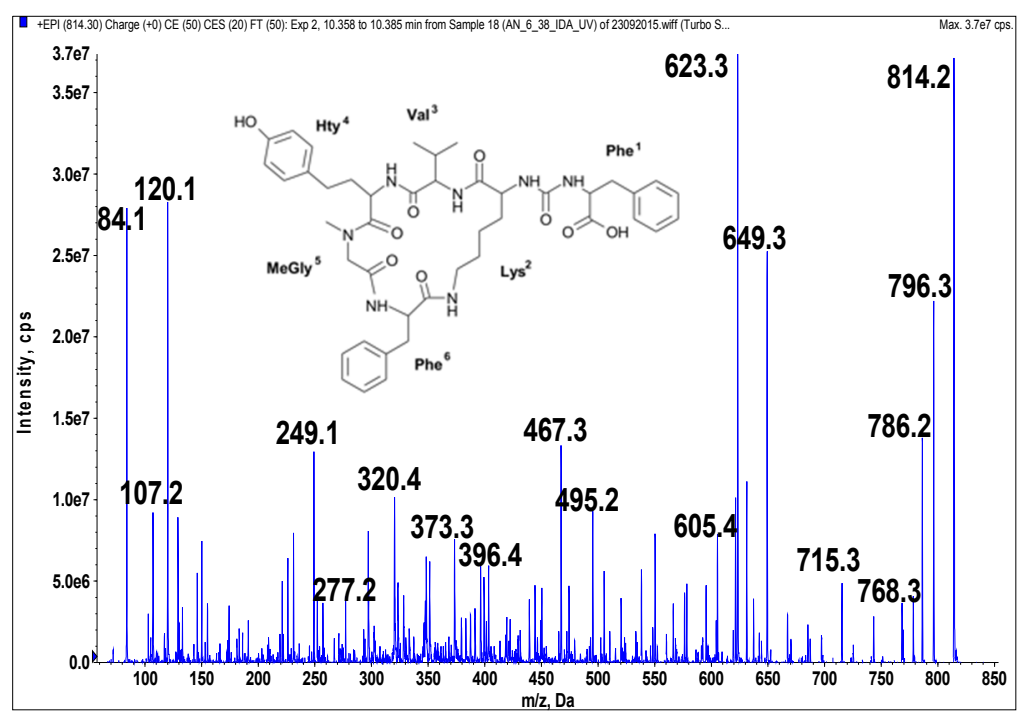

Figure 5. Schematic structure and mass fragmentation spectrum of anabaenopeptin AP 813. The structure of the peptide (Phe $+\mathrm{CO}[\mathrm{Lys}+\mathrm{Val}+\mathrm{Hty}+\mathrm{MeGly}+\mathrm{Phe}]$ ) was deduced on the basis of the following fragments: $796\left[\mathrm{M}+\mathrm{H}-\mathrm{H}_{2} \mathrm{O}\right], 786[\mathrm{M}+\mathrm{H}-\mathrm{CO}], 768\left[\mathrm{M}+\mathrm{H}-\mathrm{CO}-\mathrm{H}_{2} \mathrm{O}\right], 715$ $[\mathrm{M}+\mathrm{H}-\mathrm{Val}], 649\left[\mathrm{M}+\mathrm{H}-\mathrm{Phe}-\mathrm{H}_{2} \mathrm{O}\right], 623[\mathrm{M}+\mathrm{H}-(\mathrm{CO}+\mathrm{Phe})], 605\left[\mathrm{M}+\mathrm{H}-(\mathrm{CO}+\mathrm{Phe})-\mathrm{H}_{2} \mathrm{O}\right]$, $495[\mathrm{Phe}+\mathrm{MeGly}+\mathrm{Hty}+\mathrm{Val}+\mathrm{H}], 467[\mathrm{Phe}+\mathrm{Lys}+\mathrm{CO}+\mathrm{Phe}+\mathrm{H}], 396[\mathrm{Hty}+\mathrm{MeGly}+\mathrm{Phe}+\mathrm{H}]$, $373\left[\mathrm{M}+\mathrm{H}-\mathrm{Phe}-(\mathrm{Hty}+\mathrm{Val})-\mathrm{H}_{2} \mathrm{O}\right], 320[\mathrm{M}+\mathrm{H}-\mathrm{Phe}-(\mathrm{Val}+\mathrm{Hty}+\mathrm{MeGly}+\mathrm{Phe})], 277[\mathrm{Hty}+$ $\mathrm{Val}+\mathrm{H}], 249[\mathrm{Hty}+\mathrm{MeGly}+\mathrm{H}], 120$ Phe-immonium ion, $107\left[\mathrm{CH}_{2} \mathrm{PhOH}\right], 84$ Lys-immonium ion.

Most of the new anabaenopeptins in the sample belonged to the subclass of nodulapeptins (NPs) typical for N. spumigena harboring Met or MetO $(m / z$ 900, 856, 884 and 868$)$ and Ser or AcSer $(m / z 858$ and 866) in position 6. Nodulapeptin of $m / z 884$ (NP 883) was the main compound with a final yield of $0.022 \%$ (10.9 mg peptide per $50 \mathrm{~g}$ freeze-dried cyanobacterial material). Other major anabaenopeptins in the sample included anabaenopeptin D, anabaenopeptin A, oscillamide Y (Osc Y) as well as NP 933 $(\mathrm{m} / z$ 934) detected recently [37]. Three compounds with the same molecular weight of $899(\mathrm{~m} / \mathrm{z}$ 900) were detected, two of them previously known [24,42]. The new compound with $m / z 900$ in the bloom sample contained Hty in position 4 and MetO in position 6. This compound differed from the partly co-eluting $m / z 934$ by one residue, having Ile in position 1 instead of Phe.

Nine of the 17 anabaenopeptins in the sample contained Phe and six had Ile in the exocyclic position. Since the strains of Nodularia have been suggested to produce nodulapeptins with only one kind of residue in the exocyclic position, Ile or Phe [23,37], we assume that at least two different strains of Nodularia were present in the bloom, one producing nodulapeptins with Ile and another producing nodulapeptins with Phe in the exocyclic position. Anabaenopeptins A, D and Osc $\mathrm{Y}$ are most often isolated from Dolichospermum and Planktothrix. Mazur-Marzec et al. [37] were the first to report of anabaenopeptin D and AP 841, anabaenopeptins, other than nodulapeptins in Nodularia strains isolated from the Baltic Sea. The compound AP $841(\mathrm{~m} / z$ 842) was also detected in the present sample. The origin of the new compound AP $813(m / z$ 814) remained unclear. AP 813 has Phe in the exocyclic position and contains $\mathrm{N}$-MeGly in position 5 . Anabaenopeptins containing $\mathrm{N}$-MeGly have been previously isolated from Dolichospermum [43] and Nostoc [24]. 
Table 1. Isolated anabaenopeptins.

\begin{tabular}{|c|c|c|c|c|c|c|c|}
\hline Fraction * & $\begin{array}{l}\text { Amount of Isolated } \\
\text { Anabaenopeptin ( } \mu \mathrm{g})\end{array}$ & $\begin{array}{l}m / z \text { and Proposed Structure of Anabaenopeptin } \\
\text { Components in Fractions }\end{array}$ & $\begin{array}{l}\text { Anabaenopeptin } \\
\text { Concentration in Tested } \\
\text { Samples }(\mu \mathrm{g} / \mathrm{mL})\end{array}$ & $\begin{array}{l}\text { PP1 IC } 50 \\
\text { (ng/mL) }\end{array}$ & $\begin{array}{l}\text { Carboxypeptidase A } \\
\mathrm{IC}_{50}(\mu \mathrm{g} / \mathrm{mL})\end{array}$ & $\begin{array}{l}\text { NOD Concentration } \\
\text { in Tested Samples } \\
(\mathrm{ng} / \mathrm{mL})\end{array}$ & References \\
\hline $1(38)$ & 1305 & 934 Phe + CO[Lys + Val + Hty + MeHty + MetO $]$ & 43.5 & 16 & 20 & - & [37] \\
\hline $2(46)$ & 1287 & $\begin{array}{c}\text { 844 (Anabaenopeptin A) } \\
\text { Tyr + CO[Lys + Val + Hty + MeAla + Phe] }\end{array}$ & 42.9 & 86 & $<3$ & 43.4 & [6] \\
\hline $2(48)$ & 273 & $\begin{array}{c}\text { 844 (Anabaenopeptin A) } \\
\text { Tyr + CO[Lys + Val + Hty + MeAla + Phe }]\end{array}$ & 9.1 & 88 & $<3$ & 12.9 & [6] \\
\hline $2(50)$ & 129 & $\begin{array}{l}900 \mathrm{Ile}+\mathrm{CO}[\mathrm{Lys}+\mathrm{Val}+\mathrm{Hty}+\mathrm{MeHty}+\mathrm{MetO}] \\
934 \mathrm{Phe}+\mathrm{CO}[\mathrm{Lys}+\mathrm{Val}+\mathrm{Hty}+\mathrm{MeHty}+\mathrm{MetO}] \\
856 \text { Phe + CO[Lys + Val + Val + MeHty + MetO] }\end{array}$ & 4.3 & 40 & $<3$ & 4.8 & $\begin{array}{l}\text { New, this study } \\
{[37]} \\
\text { New, this study }\end{array}$ \\
\hline $4(50)$ & 1305 & $\begin{array}{c}858 \text { (Oscillamide Y) } \\
\text { Tyr + CO[Lys + Ile + Hty + MeAla + Phe }]\end{array}$ & 43.5 & 62 & 15 & 9.0 & [7] \\
\hline $4(51)$ & 1305 & $\begin{array}{c}858 \text { (Oscillamide Y) } \\
\text { Tyr + CO[Lys + Ile + Hty + MeAla + Phe }]\end{array}$ & 43.5 & 62 & 15 & - & [7] \\
\hline $4(52)$ & 51 & 870 Phe + CO[Lys + Val + Leu + MeHty + MetO] & 1.7 & 66 & - & - & New, this study \\
\hline $5(39 / 40)$ & 10,914 & $884 \mathrm{Ile}+\mathrm{CO}[\mathrm{Lys}+\mathrm{Val}+\mathrm{Hph}+\mathrm{MeHty}+\mathrm{MetO}]$ & 181.9 & 53 & $<3$ & - & New, this study \\
\hline $6(38)$ & 123 & 814 Phe + CO[Lys + Val + Hty + MeGly + Phe] & 4.1 & 435 & $<4$ & - & New, this study \\
\hline $6(39)$ & 252 & 916 Phe + CO[Lys + Val + Hty + MeHty + AcSer $]$ & 8.4 & 50 & $<4$ & 2.6 & [37] \\
\hline $7(39)$ & 87 & $808 \mathrm{Ile}+\mathrm{CO}[\mathrm{Lys}+\mathrm{Ile}+\mathrm{Hty}+\mathrm{MeAla}+$ Phe $]$ & 2.9 & 55 & $<25$ & 1.5 & [37] \\
\hline $8(40)$ & 2733 & $\begin{array}{c}\text { 828 (Anabaenopeptin D) } \\
\text { Phe + CO[Lys + Val + Hty + MeAla + Phe] }\end{array}$ & 91.1 & 53 & $<3$ & - & [10] \\
\hline $8(44 / 45)$ & 3816 & 918 Phe + CO[Lys + Val + Hph + MeHty + MetO] & 63.6 & 100 & $<3$ & - & [42] \\
\hline $9(44)$ & 69 & $900 \mathrm{Ile}+\mathrm{CO}[\mathrm{Lys}+\mathrm{Met}+\mathrm{Hph}+\mathrm{MeHty}+\mathrm{Met}]$ & 2.3 & 60 & $<28$ & - & [24] \\
\hline $9(45)$ & 108 & $\begin{array}{c}858 \text { Phe + CO[Lys + Val + Hph + MeHty + Ser }] \\
918 \text { Phe + CO[Lys + Val + Hph + MeHty + MetO }]\end{array}$ & 3.6 & 50 & $<20$ & - & $\begin{array}{c}\text { New, this study } \\
{[42]}\end{array}$ \\
\hline 10(51) & 579 & $866 \mathrm{Ile}+\mathrm{CO}[\mathrm{Lys}+\mathrm{Val}+\mathrm{Hph}+\mathrm{MeHty}+\mathrm{AcSer}]$ & 19.3 & 435 & 35 & - & New, this study \\
\hline $10(52)$ & 84 & $900 \mathrm{Phe}+\mathrm{CO}[\mathrm{Lys}+\mathrm{Val}+\mathrm{Hph}+\mathrm{MeHty}+\mathrm{AcSer}]$ & 2.8 & 140 & $<22$ & - & [42] \\
\hline $13(51)$ & 741 & $868 \mathrm{Ile}+\mathrm{CO}[\mathrm{Lys}+\mathrm{Val}+\mathrm{Hph}+\mathrm{MeHty}+\mathrm{Met}]$ & 24.7 & 71 & 45 & - & New, this study \\
\hline
\end{tabular}




\section{Activity Studies of the Anabaenopeptins}

All isolated fractions containing anabaenopeptins inhibited carboxypeptidase A (CPA; with the exception of one peptide variant which was present at a low concentration) and protein phosphatase 1 (PP1). The activities of the isolated anabaenopeptins are shown as $\mathrm{IC}_{50}$ values in Table 1 (determined by probit analysis as well as a graphical method using dose-response curves). Table 1 is useful for the comparison of the inhibitory activities of the peptides isolated in this study but cannot be directly used for a comparison with previous studies, as the $\mathrm{IC}_{50}$ values of the enzyme inhibitors vary depending on the assay parameters such as the nature of the enzyme, the used substrate and other experimental conditions.

The peptides showed activity with $\mathrm{IC}_{50}$ values from 16 to $435 \mathrm{ng} / \mathrm{mL}$ in the PP1 assay and from below 3 to $45 \mu \mathrm{g} / \mathrm{mL}$ in the CPA assay. Anabaenopeptin 869 in fraction 4(52) did not inhibit the carboxypeptidase A at the tested concentration. The activities of the fractions consisting of more than one anabaenopeptin are the summed effect of the anabaenopeptins present. Acquired standards of anabaenopeptins A, B and J as well as Osc $\mathrm{Y}$ were tested for activity towards carboxypeptidase A and protein phosphatase 1. All four compounds showed inhibition of PP1. Anabaenopeptin J and Osc Y were additionally active against CPA. The presence of nodularin complicated the interpretation of enzymatic activities towards PP1 in some fractions. No anabaenopeptins isolated in this study induced inhibition of elastase, trypsin or thrombin, irrespective of the residue in the exocyclic position (Phe, Ile and Tyr).

Substitutions of the amino acid residues are thought to determine the degree of protease inhibition as well as the protease specificity of the compounds [44]. Recent computational docking studies have shown the importance of the aliphatic part of the D-Lys and its stereochemistry as well as the importance of the residues adjacent to the urea bond in interacting with the active binding pocket of carboxypeptidase A [27,45]. Thirteen of the anabaenopeptins presented in Table 1 have the aromatic residue Phe, five have Ile and four Tyr in the exocyclic position. The CPA inhibition activities of all these anabaenopeptins irrespective of the amino acid in position 1 varied from weak to more potent. Thus, more than one element of the structure has an effect on the activity of anabaenopeptins. Anabaenopeptins with exocyclic Ile and Tyr have been shown to inhibit CPA strongly with $\mathrm{IC}_{50}$ values of $0.0052-0.022 \mu \mathrm{g} / \mathrm{mL}$ (hippur-L-phenylalanine as a substrate) $[14,25,46]$. The CPA inhibition by anabaenopeptin $\mathrm{H}$ having exocyclic Arg was shown to be a weaker although still a potent inhibitor with $\mathrm{IC}_{50}$ of $3.4 \mu \mathrm{g} / \mathrm{mL}$ [14]. No Arg-containing anabaenopeptins were among the isolated and tested anabaenopeptins in our sample, although some anabaenopeptin E was detected during the purification. We have been unable to locate literature on anabaenopeptins with Phe in the exocyclic position inhibiting CPA so far. Our work demonstrates for the first time the ability of nodulapeptins with either Ile or Phe in the exocyclic position to inhibit CPA.

The cyclic hepta- and pentapeptides, microcystins and nodularins, are the most extensively studied toxic secondary metabolites of cyanobacteria. Microcystins and nodularins exhibit their toxicity by inhibition of protein serine/threonine phosphatases type 1 (PP1) and 2A (PP2A) [47]. Microcystins and nodularins are considered to be potent PP1 inhibitors, with reported $\mathrm{IC}_{50}$-values of $1.1-1.9 \mathrm{nM}[48,49]$. All isolated anabaenopeptins presented in Table 1 inhibited protein phosphatase 1 but clearly with lower potencies than the toxins. The influence of nodularin to the PP1 inhibition cannot be excluded when present in the fraction.

The comparison of the PP1 inhibition of different anabaenopeptins in our sample with previously discovered anabaenopeptins is hampered by the low number of studies performed on this issue. The inhibition of PP1 (from rabbit skeletal muscle) by anabaenopeptins has been reported for oscillamides B, C, and anabaenopeptin F [31] as well as for anabaenopeptin A and B [32]. The presence of Arg in the exocyclic position in all these active compounds were deduced to be linked to the inhibitory activity. Osc $\mathrm{Y}$ with $\mathrm{N}$-MeAla at position 5 and exocyclic Tyr was considered only a weak inhibitor of PP1 (no effect even at $100 \mu \mathrm{g} / \mathrm{mL}$ ) compared to oscillamide B, C and anabaenopeptin F. The $\mathrm{IC}_{50}$ value was reported only for Osc $\mathrm{C}$ which was $0.9 \mu \mathrm{M}$ [31]. In our study, Osc Y showed 
inhibitory activity with $\mathrm{IC}_{50}$ of $62 \mathrm{ng} / \mathrm{mL}$ which was higher than that of anabaenopeptin A, with two isomeric forms chromatographed in fractions 2(46) and 2(48) and coeluting with nodularin. The $\mathrm{IC}_{50}$ values of the isomeric forms of anabaenopeptin A were 86 and $88 \mathrm{ng} / \mathrm{mL}$. No Arg-containing anabaenopeptins were isolated from our sample. Our results showed that all of the 14 isolated APs and NPs inhibited protein phosphatase 1.

\section{Experimental Section}

\subsection{Reagents}

Water was purified to $18.2 \mathrm{M} \Omega \mathrm{cm}$ on a Milli-Q Synthesis system (Molsheim, France). Methanol, HPLC gradient grade, was from Merck (Darmstadt, Germany). Acetic acid, formic acid, trifluoroacetic acid and LC-MS grade acetonitrile were purchased from Sigma-Aldrich (St. Louis, MO, USA).

The following reagents used for enzymatic assays were purchased from Sigma-Aldrich: trypsin (product number T0303), thrombin bovine plasma (T4648), elastase (E0258), carboxypeptidase A (C9268), aprotinine (A6103), N-p-tosyl-Gly-Pro-Lys-p-nitroanilide acetate salt (T6140), N-Succinyl-GlyGly-Phe-p-nitroanilide (S1899), 4-(2-Aminoethyl) benzenesulfonyl fluoride hydrochloride-AEBSF (A8456), elastatinal (E0881), N-Succinyl-Ala-Ala-Ala-p-nitroanilide (S4760), carboxypeptidase inhibitor-CPI (C0297), p-nitrophenyl phosphate disodium salt hexahydrate-p-NPP (71768), albumin bovine-BSA (A4503) and DL-dithiothreitol DTT (D0632).

Protein phosphatase 1-PP1 was from New England Biolabs (Ipswich, MA, USA). $N_{\alpha}$-benzoyl-L-arginine 4-nitroanilide hydrochloride-BAPNA (ACROS 227740050) was from Acros Organics (Geel, Belgium). N-(4-methoxyphenylazoformyl)-Phe-OH (M-2245.0100) was purchased from Bachem (Bubendorf, Switzerland). In addition, the following analytical reference materials were used: CRM-Nodularin (IBM-NRC, Halifax, NS, Canada), anabaenopeptin A and B (Enzo Life Sciences, Lausen, Switzerland), anabaenopeptin J and oscillamide Y (Cyano Biotech, Berlin, Germany).

\subsection{Sampling and Extraction of the Cell Material}

Cyanobacterial material was collected with a plankton net (100 $\mu \mathrm{m}$ mesh size) from the Gulf of Gdansk, close to Gdynia-Redłowo, on 5 July 2012. The cyanobacterial community in the bloom sample was composed of Nodularia spumigena (50\% of the cyanobacterial biomass), Aphanizomenon flos-aquae (40\%) and Dolichospermum spp. (10\%). The freeze-dried material (50 g) was extracted with 5\% acetic acid in water $(500 \mathrm{~mL})$ by 5-min probe sonication (HD2070 Sonopuls ultrasonic disrupter, Bandelin, Berlin, Germany) followed by $15 \mathrm{~min}$ bath sonication. The extract was centrifuged (10,000 rpm, $15 \mathrm{~min}$ ) and the remaining residue was re-extracted three times with $500 \mathrm{~mL}$ of $5 \%(v / v)$ acetic acid. Additionally, two extractions were done with $500 \mathrm{~mL}$ of $60 \%$ methanol in water. The methanolic extracts were combined, evaporated in vacuum evaporator with water bath $\left(35^{\circ} \mathrm{C}\right)$ and dissolved in $300 \mathrm{~mL}$ of $5 \%$ acetic acid. Finally, all the extracts were combined, centrifuged $(10,000 \mathrm{rpm}, 15 \mathrm{~min})$ and filtered through Whatman glassfibre filters, type GF/C (Maidstone, UK) discs. The total volume of the extract was $2.3 \mathrm{~L}$.

\subsection{Fractionation of Peptides by Solid-Phase Extraction (SPE)}

For the first SPE, the extract was divided in aliquots of approx. $550 \mathrm{~mL}$, and applied on six Sep-Pak Vac $10 \mathrm{~g} 35 \mathrm{cc}$ cartridges with $\mathrm{tC}_{18}$ resin (Waters, Milford, MA, USA). The adsorbed substances were eluted from each cartridge with $120 \mathrm{~mL}$ of $75 \%$ methanol in water and the eluates were rotary evaporated to dryness. The residues were dissolved in a total volume of $300 \mathrm{~mL}$ of $5 \%$ acetic acid for the second extraction step on six 6-g OASIS HLB (Hydrophilic-Lipophilic-Balanced) cartridges (Waters). The material adsorbed to each cartridge was sequentially eluted and fractionated with $20 \%$ $(100 \mathrm{~mL}), 40 \%(300 \mathrm{~mL}), 50 \%(250 \mathrm{~mL})$ and $80 \%(500 \mathrm{~mL})$ methanol in water with $0.1 \%(v / v)$ formic acid (FA). The fractions eluted with $80 \%$ methanol with $0.1 \%$ FA, which contained the majority of the peptides as monitored by LC-MS/MS, were combined and evaporated to dryness and dissolved in 
$150 \mathrm{~mL}$ of $5 \%$ acetic acid. This solution was subjected to further purification (third SPE) using three 1-g HLB cartridges. Sequential elution was performed with $50 \mathrm{~mL}$ of $20 \%, 30 \%, 40 \%, 50 \%$ and $60 \%$ methanol containing $0.1 \%(v / v)$ FA and then with $300 \mathrm{~mL}$ of $80 \%$ methanol containing $0.1 \%$ FA. The $80 \%$ methanolic eluates with $0.1 \%$ FA, containing anabaenopeptins, were combined and evaporated in a rotary evaporator. The dry residue was dissolved in $10 \mathrm{~mL}$ of $15 \%$ methanol, centrifuged and the supernatant was filtered through a Pall (Ann Arbor, MI, USA) GF/C-GHP (polypropylene membrane with a built-in glassfibre prefilter) Acrodisc $25 \mathrm{~mm}$ syringe filter. Dilutions of the resulting solution and the purchased standard peptides were used to optimize the chromatographic conditions in analytical and preparative HPLC as well as the mass spectrometric conditions.

\subsection{Monitoring of Peptides by Analytical HPLC}

The analytical separations were carried out on a Agilent (Waldbronn, Germany) 1100 Series HPLC system consisting of degasser, quaternary pump, thermostated column compartment at $40{ }^{\circ} \mathrm{C}$ and diode-array detector. The peptides were monitored at $214 \mathrm{~nm}, 238 \mathrm{~nm}$ and $280 \mathrm{~nm}$ and UV spectra were recorded at 200-300 nm. Separation was achieved on a Synergi $2.5 \mu \mathrm{m}$ Polar-RP 100 A, $100 \mathrm{~mm} \times 3.0 \mathrm{~mm}$ I.D. (Phenomenex, Torrance, CA, USA) column with a compatible guard column. The mobile phase system consisted of A: 0.05\% trifluoroacetic acid (TFA) in water and B: $0.05 \%$ TFA in acetonitrile. The following linear gradient was employed: 0 min 10\% B, 20 min 60\% B, 21 min $60 \% \mathrm{~B}$ and $21.1 \mathrm{~min} 10 \% \mathrm{~B}$. Flow-rate was $0.5 \mathrm{~mL} \cdot \mathrm{min}^{-1}$. The concentrations of the anabaenopeptins were calculated by comparing the peak-areas at $214 \mathrm{~nm}$ with the mean peak areas of the standards anabaenopeptins A and B (both $10 \mu \mathrm{g} \cdot \mathrm{mL}^{-1}$ ).

\subsection{Isolation of Anabaenopeptins with Dual Preparative HPLC}

The preparative HPLC system consisted of Merck-Hitachi (Tokyo, Japan) LaChrom Series HPLC pump with a $10 \mathrm{~mL}$ injection loop and the photodiode-array detector set at $270 \mathrm{~nm}$. A CTO-10AV column oven (Shimadzu, Suzhou, China) was thermostated at $40{ }^{\circ} \mathrm{C}$. The first step in the purification of anabaenopeptins (System 1) was conducted on a Synergi $4 \mu \mathrm{m}$ Polar-RP $80 \mathrm{~A}, 250 \mathrm{~mm} \times 10 \mathrm{~mm}$, column (Phenomenex, Torrance, CA, USA). The mobile phase system consisted of A: 0.05\% TFA in water and B: $0.05 \%$ TFA in acetonitrile. The gradient was from $32 \%$ B to $42 \%$ B over $80 \mathrm{~min}$. The flow-rate was initially $3 \mathrm{~mL} \cdot \mathrm{min}^{-1}$ but it was increased to $4 \mathrm{~mL} \cdot \mathrm{min}^{-1}$ at $3 \mathrm{~min}$. $0.5 \mathrm{~min}$ fractions $(2 \mathrm{~mL})$ were collected by a fraction collector (Gilson, Middleton, MI, USA).

The second preparative HPLC system (System 2) was as depicted above except for the solvent system which consisted of A: ammonium acetate in water (15 g/L) -acetonitrile (ACN) (95:5) and B: ammonium acetate in water $(30 \mathrm{~g} / \mathrm{L})$ - ACN (50:50). The gradient was from $20 \% \mathrm{~B}$ to $95 \%$ B over $80 \mathrm{~min}$, increasing to $100 \% \mathrm{~B}$ at $85 \mathrm{~min}$ and back to $20 \% \mathrm{~B}$ at $98 \mathrm{~min}$. The flow-rate was as given above.

The $10 \mathrm{~mL}$ of sample containing anabaenopeptins dissolved in 15\% methanol was separated according to the preparative System 1. 0.5-min fractions were collected. All fractions were analyzed by flow injection analysis-MS/MS (FIA-MS/MS). Fractions containing anabaenopeptins were diluted with water and concentrated on $400 \mathrm{mg}$ OASIS HLB cartridges. The peptides were eluted with $2+2 \mathrm{~mL}$ of $100 \%$ methanol. Aqueous dilutions were made of the SPE eluates and analysed both by analytical HPLC (Synergi Polar column TFA-ACN mobile phase) and FIA-MS/MS. The eluates containing the compounds of interest (15 samples) were evaporated to nearly dryness and each sample was dissolved in $3 \mathrm{~mL}$ of $15 \%$ methanol containing ammonium acetate $(1.5 \mathrm{~g} / 100 \mathrm{~mL})$ before separation in the preparative System 2 . This time $1 \mathrm{~min}$ fractions were collected. Fractions containing anabaenopeptins were diluted and analysed by HPLC and FIA-MS/MS. The purified fractions were desalted and concentrated on $200 \mathrm{mg}$ or $400 \mathrm{mg}$ OASIS HLB cartridges for further testing in various enzymatic assays. 


\section{6. $L C-M S / M S$}

The structures of the cyanobacterial peptides were characterized by Applied Biosystems Sciex (Concorde, ON, Canada) QTRAP 5500 LC-MS/MS as described by Mazur-Marzec et al. (2013) [37], but the collision energy (CE) was set at $50 \mathrm{~V}$. In the samples subjected to enzymatic assays, the presence of nodularin was additionally analyzed using multiple reaction monitoring mode with the following transition ions $825 \rightarrow 135$ (quantifier, CE 60), $825 \rightarrow 389$ (CE 55), $825 \rightarrow 227$ (CE 55). The detection limit of nodularin in MRM mode was $0.2 \mathrm{ng} / \mathrm{mL}$ ( $5 \mu \mathrm{L}$ sample injected).

\subsection{FIA-MS/MS}

The FIA-MS/MS experiments were carried out on an Agilent Technologies (Waldbronn, Germany) 1200 Rapid Resolution (RR) LC coupled to a Bruker Daltonics HCT Ultra Ion trap MS (Bremen, Germany). The ion trap MS was operated in the positive electrospray ion mode. The Ion Charge Control (ICC) target was set to 200,000 with a maximum accumulation time of $200 \mathrm{~ms}$. The capillary voltage was set at $4.0 \mathrm{kV}$. The ion source parameters were set as follows: dry temperature $350{ }^{\circ} \mathrm{C}$, nebulizer pressure $30 \mathrm{psi}$ and dry gas flow $8.0 \mathrm{~L} / \mathrm{min}$. The mobile phase consisted of solvents $\mathrm{A}$ : $99 \%$ water $-1 \% \mathrm{ACN}-0.1 \% \mathrm{FA}$ and $\mathrm{B}: \mathrm{ACN}-0.1 \% \mathrm{FA}$. Flow injection analysis was performed under isocratic conditions with $50 \% \mathrm{~B}$.

\subsection{Enzymatic Assays}

APs were assayed for bioactivity by protein phosphatase 1, carboxypeptidase A, trypsin, elastase and thrombin inhibition assays as described in Mazur-Marzec et al. 2015 [50]. Some details of the performed assays are presented in Table 2 .

Table 2. Conditions under which the protein phosphatases and proteases inhibition assays were performed ( $p$-NPP 4-nitrophenyl phosphate disodium salt hexahydrate; BAPNA $N_{\alpha}$-benzoyl-L-arginine 4-nitroanilide hydrochloride; AEBSF 4-(2-aminoethyl)benzenesulfonyl fluoride hydrochloride).

\begin{tabular}{|c|c|c|c|c|c|c|}
\hline Inhibition Assay & Substrate & Inhibitor & $\begin{array}{l}\text { Preincubation } \\
\text { Time (min) }\end{array}$ & $\begin{array}{l}\text { Reaction } \\
\text { Time } \\
\text { (min) }\end{array}$ & $\begin{array}{l}\text { Reaction } \\
\text { Temperature } \\
\left({ }^{\circ} \mathrm{C}\right)\end{array}$ & $\begin{array}{c}\text { Wave } \\
\text { Length } \\
(\mathrm{nm})\end{array}$ \\
\hline $\begin{array}{l}\text { Protein phosphatase } \\
\text { (PP1) }\end{array}$ & $p$-NPP & Nodularin & - & 120 & 37 & 405 \\
\hline Trypsin & BAPNA & Aprotinine & 15 & 5 & 25 & 405 \\
\hline Thrombin & $\begin{array}{l}N-p \text {-tosyl-Gly-Pro-Lys- } p \text {-nitroanilide } \\
\text { acetate salt }\end{array}$ & AEBSF & 10 & - & 37 & 405 \\
\hline Elastase & $\begin{array}{c}2 \mathrm{mM} \text { of } \\
\mathrm{N} \text {-succinyl-Ala-Ala-Ala-p-nitroanilide }\end{array}$ & Elastatinal & 15 & 10 & 25 & 405 \\
\hline Carboxypeptidase A & $\mathrm{N}$-(4-methoxy-phenyl-azoformyl)-Phe-OH & $\begin{array}{l}\text { Carboxypeptidase } \\
\text { inhibitor from } \\
\text { potato tuber (CPI) }\end{array}$ & 5 & 15 & 37 & 350 \\
\hline
\end{tabular}

\section{Conclusions}

A bloom sample of Baltic Sea cyanobacteria comprised of Nodularia, Dolichospermum and Aphanizomenon was extracted and fractionated. Fourteen anabaenopeptins were isolated and determined structurally by LC-MS/MS. Most of the isolated compounds were nodulapeptins, a subclass of anabaenopeptins typical for $N$. spumigena. Eight novel anabaenopeptins were discovered, five isolated with no co-eluting peptides. All anabaenopeptins showed activity towards PP1 and carboxypeptidase A (with the exception of one variant), but no inhibition against chymotrypsin, trypsin and thrombin was observed.

Acknowledgments: This study was financially supported by a grant from Svenska Litteratursällskapet i Finland to LS, the EU project MAREX (245137, within KBBE-2009-3-2-01) and the National Science Centre in Poland (NCN2013/0518/B/NZ8/01222) to HMM and AB. COST action ES1105 "CYANOCOST_Cyanobacterial blooms 
and toxins in water resources: Occurrence, impacts and management" is acknowledged for adding value to this study through networking and knowledge sharing with European experts.

Author Contributions: Lisa Spoof participated in the study design and the acquisition of research funding, had overall responsibility for and participated in the chromatographic and mass spectrometric work at Åbo Akademi University including related result interpretation, compiled the information concerning known anabaenopeptins (Supplementary Material 1), and wrote the manuscript. Agata Błaszczyk participated in the extraction procedures and fractionation, performed and interpreted the enzymatic assays, and prepared the figures. Jussi Meriluoto participated in the study design and the acquisition of research funding, participated in the chromatographic and mass spectrometric work at Åbo Akademi University, and contributed to the manuscript preparation. Marta Cegłowska performed a major part of the extraction, including all steps of solid-phase extraction. Hanna Mazur-Marzec participated in the study design and the acquisition of research funding, performed the LC-MS/MS analyses at University of Gdansk, elucidated the structures of anabaenopeptins, and contributed to the manuscript preparation.

Conflicts of Interest: The authors declare no conflicts of interest.

\section{References}

1. Singh, R.K.; Tiwari, S.P.; Rai, A.K.; Mohapatra, T.M. Cyanobacteria: An emerging source for drug discovery. J. Antibiot. 2011, 64, 410-412. [CrossRef] [PubMed]

2. Chlipala, G.E.; Mo, S.; Orjala, J. Chemodiversity in freshwater and terrestrial cyanobacteria-A source for drug discovery. Curr. Drug Targets 2011, 12, 1654-1673. [CrossRef] [PubMed]

3. Nagarajan, M.; Maruthanayagam, V.; Sundararaman, M. SAR analysis and bioactive potentials of freshwater and terrestrial cyanobacterial compounds: A review. J. Appl. Toxicol. 2012, 33, 313-349. [CrossRef] [PubMed]

4. Welker, M.; von Döhren, H. Cyanobacterial peptides-Nature's own combinatorial biosynthesis. FEMS Microbiol. Rev. 2006, 30, 530-563. [CrossRef] [PubMed]

5. Fewer, D.P.; Jokela, J.; Paukku, E.; Österholm, J.; Wahlsten, M.; Permi, P.; Aitio, O.; Rouhiainen, L.; Gomeez-Saez, G.V.; Sivonen, K. New structural variants of aeruginosins produced by the toxic bloom forming cyanobacterium Nodularia spumigena. PLoS ONE 2013, 8, e73618. [CrossRef] [PubMed]

6. Harada, K.-I.; Fujii, K.; Shimada, T.; Suzuki, M. Two cyclic peptides, anabaenopeptins, a third group of bioactive compounds from the cyanobacterium Anabaena flos-aquae NRC 525-17. Tetrahedron Lett. 1995, 36, 1511-1514. [CrossRef]

7. Sano, T.; Kaya, K. Oscillamide Y, a chymotrypsin inhibitor from toxic Oscillatoria agardhii. Tetrahedron Lett. 1995, 36, 5933-5936. [CrossRef]

8. Fujii, K.; Sivonen, K.; Adachi, K.; Noguchi, K.; Shimizu, Y.; Sano, H.; Hirayama, K.; Suzuki, M.; Harada, K.-I. Comparative study of toxic and non-toxic cyanobacterial products: Novel peptides from toxic Nodularia spumigena AV1. Tetrahedron Lett. 1997, 38, 5529-5532. [CrossRef]

9. Williams, D.E.; Graig, M.; Holmes, C.F.B.; Andersen, R.J. Ferintoic acids A and B, new cyclic hexapeptides from the freshwater cyanobacterium Microcystis aeruginosa. J. Nat. Prod. 1996, 59, 570-575. [CrossRef]

10. Fujii, K.; Harada, K-I.; Suzuki, M.; Kondo, F.; Ikai, Y.; Oka, H.; Carmichael, W.W.; Sivonen, K. Occurrence of novel cyclic peptides together with microcystins from toxic cyanobacteria, Anabaena species. In Harmful and Toxic Algal Blooms; Yasumoto, T., Oshima, Y., Fukuyo, Y., Eds.; Intergovernmental Oceanographic Commission of UNESCO: Paris, France, 1996; pp. 559-562.

11. Shin, H.J.; Matsuda, H.; Murakami, M.; Yamaguchi, K. Anabaenopeptins E and F, two new cyclic peptides from the cyanobacterium Oscillatoria agardhii (NIES-204). J. Nat. Prod. 1997, 60, 139-141. [CrossRef]

12. Zi, J.; Lantvit, D.D.; Swanson, S.M.; Orjala, J. Lyngbyaureidamides A and B, two anabaenopeptins from the cultured freshwater cyanobacterium Lyngbya sp. (SAG 36.91). Phytochemistry 2012, 74, 173-177. [CrossRef] [PubMed]

13. Matthew, S.; Ross, C.; Paul, V.J.; Luesch, H. Pompanopeptins A and B, new cyclic peptides from the marine cyanobacterium Lyngbya confervoides. Tetrahedron 2008, 64, 4081-4089. [CrossRef]

14. Murakami, M.; Suzuki, S.; Itou, Y.; Kodani, S.; Ishida, K. New anabaenopeptins, potent carboxypeptidase-A inhibitors from the cyanobacterium Aphanizomenon flos-aquae. J. Nat. Prod. 2000, 63, 1280-1282. [CrossRef] [PubMed]

15. Kobayashi, J.; Sato, M.; Ishibashi, M.; Shigemori, H.; Nakamura, T.; Ohizumi, Y. Keramamide A, a novel peptide from the Okinawan sponge Theonella sp. J. Chem. Soc. Perkin Trans. 1991, 1, 2609-2611. [CrossRef] 
16. Kobayashi, J.; Sato, M.; Murayama, T.; Ishibashi, M.; Wälchi, M.R.; Kanai, M.; Shoji, J.; Ohizumi, Y. Konbamide, a novel peptide with calmodulin antagonistic activity from the Okinawan marine sponge Theonella sp. J. Chem. Soc. Chem. Commun. 1991, 15, 1050-1052. [CrossRef]

17. Schmidt, E.W.; Harper, M.K.; Faulkner, D.J. Mozamides A and B, cyclic peptides from theonellid sponge from Mozambique. J. Nat. Prod. 1997, 60, 779-782. [CrossRef]

18. Müller, D.; Krick, A.; Kehraus, S.; Mehner, C.; Hart, M.; Küpper, F.J.; Saxena, K.; Prinz, H.; Schwalbe, H.; Janning, P.; et al. Brunsvicamides A-C: Sponge-related cyanobacterial peptides with Mycobacterium tuberculosis protein tyrosine phosphatase inhibitory activity. J. Med. Chem. 2006, 49, 4871-4878. [CrossRef] [PubMed]

19. Namikoshi, M.; Rinehart, K.L. Bioactive compounds produced by cyanobacteria. J. Ind. Microbiol. 1996, 17, 373-384. [CrossRef]

20. Reshef, V.; Carmeli, S. Schizopeptin 791, a new anabaenopeptin-like cyclic peptide from the cyanobacterium Schizothrix sp. J. Nat. Prod. 2002, 65, 1187-1189. [CrossRef] [PubMed]

21. Sanz, M.; Andreote, A.P.D.; Fiore, M.F.; Dörr, F.A.; Pinto, E. Structural characterization of new peptide variants produced by cyanobacteria from Brazilian Atlantic coastal forest using liquid chromatography coupled to quadrupole time-of-flight mass spectrometry. Mar. Drugs 2015, 13, 3892-3919. [CrossRef] [PubMed]

22. Plaza, A.; Keffer, J.L.; Lloyd, J.R.; Colin, P.L.; Bewley, C.A. Paltolides A-C, anabaenopeptin-type peptides from the Palau sponge Theonella swinhoei. J. Nat. Prod. 2010, 73, 485-488. [CrossRef] [PubMed]

23. Christiansen, G.; Philmus, B.; Hemscheidt, T.; Kurmayer, R. Genetic variation of adenylation domains of the anabaenopeptin synthesis operon and evolution of substrate promiscuity. J. Bacteriol. 2011, 193, 3822-3831. [CrossRef] [PubMed]

24. Rouhiainen, L.; Jokela, J.; Fewer, D.P.; Urmann, M.; Sivonen, K. Two alternative starter modules for the non-ribosomal biosynthesis of specific anabaenopeptin variants in Anabaena (cyanobacteria). Chem. Biol. 2010, 17, 265-273. [CrossRef] [PubMed]

25. Kodani, S.; Suzuki, S.; Ishida, K.; Murakami, M. Five new cyanobacterial peptides from water bloom materials of lake Teganuma (Japan). FEMS Microbiol. Lett. 1999, 178, 343-348. [CrossRef]

26. Björkquist, P. Use of Cyclic Anabaenopeptin-Type Peptides for the Treatment of a Condition wherein Inhibition of Carboxypeptidase U Is Beneficial, Novel Anabaenopeptin Derivatives and Intermediates Thereof. U.S. Patent 2,005,039,617, 6 May 2005.

27. Halland, N.; Brönstrup, M.; Czech, J.; Czechtizky, W.; Evers, A.; Follmann, M.; Kohlmann, M.; Schiell, M.; Kurz, M.; Schreuder, H.A.; et al. Novel small molecule inhibitors of activated thrombin activatable fibrinolysis inhibitor (TAFIa) from natural product anabaenopeptin. J. Med. Chem. 2014, 58, 4839-4844. [CrossRef] [PubMed]

28. Repka, S.; Koivula, M.; Harjunpää, V.; Rouhiainen, L.; Sivonen, K. Effects of phosphate and light on growth of and bioactive peptide production by the cyanobacterium Anabaena strain 90 and its anabaenopeptilide mutant. Appl. Environ. Microbiol. 2004, 70, 4551-4560. [CrossRef] [PubMed]

29. Bubik, A.; Sedmak, B.; Novinec, M.; Lenarčič, B.; Lah, T.T. Cytotoxic and peptidase inhibitory activities of selected non-hepatotoxic cyclic peptides from cyanobacteria. Biol. Chem. 2008, 389, 1339-1346. [CrossRef] [PubMed]

30. Zafrir-Ilan, E.; Carmeli, S. Eight novel serine proteases inhibitors from a water bloom of the cyanobacterium Microcystis sp. Tetrahedron 2010, 66, 9194-9202. [CrossRef]

31. Sano, T.; Usui, T.; Ueda, K.; Osada, H.; Kaya, K. Isolation of new protein phosphatase inhibitors from two cyanobacterial species, Planktothrix spp. J. Nat. Prod. 2001, 64, 1052-1055. [CrossRef] [PubMed]

32. Gkelis, S.; Lanaras, T.; Sivonen, K. The presence of microcystins and other cyanobacterial bioactive peptides in aquatic fauna collected from Greek freshwaters. Aquat. Toxicol. 2006, 78, 32-41. [CrossRef] [PubMed]

33. Sønstebø, J.H.; Rohrlack, T. Possible implications of chytrid parasitism for population subdivisions in freshwater cyanobacteria of the genus Planktothrix. Appl. Environ. Microbiol. 2011, 77, 1344-1351. [CrossRef] [PubMed]

34. Urrutia-Cordero, P.; Agha, R.; Cirés, S.; Ángeles Lezcano, M.; Sánchez-Contreras, M.; Waara, K-O.; Utkilen, H.; Quesada, A. Effects of harmful cyanobacteria on the freshwater pathogenic free-living amoeba Acanthamoeba castellanii. Aquat. Toxicol. 2013, 130, 9-17. [CrossRef] [PubMed] 
35. Sedmak, B.; Carmeli, S.; Eleršek, T. "Non-toxic" cyclic peptides induce lysis of cyanobacteria-An effective cell population density control mechanism in cyanobacterial blooms. Microbiol. Ecol. 2008, 56, 201-209. [CrossRef] [PubMed]

36. Karlsson, K.M.; Kankaanpää, H.; Huttunen, M.; Meriluoto, J. First observation of microcystin-LR in pelagic cyanobacterial blooms in northern Baltic Sea. Harmful Algae 2005, 4, 163-166. [CrossRef]

37. Mazur-Marzec, H.; Kaczkowska, M.J.; Blaszczyk, A.; Ackaalan, R.; Spoof, L.; Meriluoto, J. Diversity of peptides produced by Nodularia spumigena from various geographical regions. Mar. Drugs 2013, 11, 1-19. [CrossRef] [PubMed]

38. Neilan, B.A.; Dittmann, E.; Rouhiainen, L.; Bass, A.; Schaub, V.; Sivonen, K.; Börner, T. Nonribosomal peptide synthesis and toxigenicity of cyanobacteria. J. Bacteriol. 1999, 181, 4089-4097. [PubMed]

39. Fujii, K.; Mayumi, T.; Noguchi, K.; Kashiwagi, T.; Akashi, S.; Sivonen, K.; Hirayama, K.; Harada, K.-I. Mass spectrometric studies of peptides from cyanobacteria under FAB MS/MS conditions. J. Mass Spectrom. Soc. Jpn. 2000, 48, 56-64. [CrossRef]

40. Erhard, M.; von Döhre, H.; Jungblut, P. Rapid typing and elucidation of new secondary metabolites of intact cyanobacteria using MALDI-TOF mass spectrometry. Nat. Biotechnol. 1997, 15, 906-909. [CrossRef] [PubMed]

41. Ferranti, P.; Fabbrocino, S.; Chiaravalle, E.; Bruno, M.; Basile, A.; Serpe, L.; Gallo, P. Profiling microcystin contamination in a water reservoir by MALDI-TOF and liquid chromatography coupled to Q/TOF tandem mass spectrometry. Food Res. Int. 2013, 54, 1321-1330. [CrossRef]

42. Schumacher, M.; Wilson, N.; Tabudravu, J.N.; Edwards, C.; Lawton, L.A.; Motti, C.; Wright, A.D.; Diederich, M.; Jaspars, M. New nodulopeptins from Nodularia spumigena KAC 66. Tetrahedron 2012, 68, 1622-1628. [CrossRef]

43. Grach-Progrebinsky, O.; Carmeli, S. Three novel anabaenopeptins from the cyanobacterium Anabaena sp. Tetrahedron 2008, 64, 10233-10238. [CrossRef]

44. Gesner-Apter, S.; Carmeli, S. Protease inhibitors from a water bloom of the cyanobacterium Microcystis aeruginosa. J. Nat. Prod. 2009, 72, 1429-1436. [CrossRef] [PubMed]

45. Walther, T.; Renner, S.; Waldmann, H.; Arndt, H-D. Synthesis and structure-activity correlation of a brunsvicamide-inspired cyclopeptide collection. ChemBioChem 2009, 10, 1153-1162. [CrossRef] [PubMed]

46. Itou, Y.; Suzuki, S.; Ishida, K.; Murakami, M. Anabaenopeptins G and H, potent carboxypeptidase A inhibitors from the cyanobacterium Oscillatoria agardhii (NIES-595). Biorgan. Med. Chem. Lett. 1999, 9, 1243-1246. [CrossRef]

47. MacKintosh, C.; Beattie, K.A.; Klumpp, S.; Cohen, P.; Codd, G.A. Cyanobacterial microcystin-LR is a potent and specific inhibitor of protein phophatases 1 and 2A from both mammals and higher plants. FEBS Lett. 1990, 264, 187-192. [CrossRef]

48. Fischer, A.; Hoeger, S.J.; Stemmer, K.; Feuerstein, D.J.; Knobeloch, D.; Nussler, A.; Dietrich, D.R. The role of organic anion transporting polypeptides (OATPs/SLCOs) in the toxicity of different microcystin congeners in vitro: A comparison of primary human hepatocytes and OATP-transfected HEK293 cells. Toxicol. Appl. Pharmacol. 2010, 245, 9-20. [CrossRef] [PubMed]

49. Honkanen, R.E.; Dukelow, M.; Zwiller, J.; Moore, R.E.; Khatra, B.S.; Boynton, A.L. Cyanobacterial nodularin is a potent inhibitor of type 1 and type 2A protein phosphatases. Mol. Pharmacol. 1991, 40, 577-583. [PubMed]

50. Mazur-Marzec, H.; Blaszczyk, A.; Felczykowska, A.; Hohlfeld, N.; Kobos, J.; Toruńska-Sitarz, A.; Devi, P.; Montalvão, S.; D'Souza, L.; Tammela, P.; et al. Baltic cyanobacteria-A source of biologically active compounds. Eur. J. Phycol. 2015, 50, 343-360. [CrossRef]

(C) 2015 by the authors; licensee MDPI, Basel, Switzerland. This article is an open access article distributed under the terms and conditions of the Creative Commons by Attribution (CC-BY) license (http://creativecommons.org/licenses/by/4.0/). 